\title{
Assessment of natural vegetal extracts in the inhibition of Leuconostoc mesenteroides MS1
}

Serra, M. A., Garnero, J. A., Nicolau, V. V. and Andreatta, A. E.

\begin{abstract}
SUMMARY
The present study focuses on the assessment of natural vegetal extracts in the inhibition of bacteria altering Vienna sausages whose growth becomes evident in the vacuum packed product after two to three weeks of refrigerated storage causing packages to swell. The different natural extracts were obtained by means of steam stripping, microwave assisted extraction and ultrasound assisted extraction. Apart from these extracts, commercial essential oils, pure compounds present in the vegetal kingdom and solutions were also evaluated. For each of the extracts, microbial sensitivity tests were carried out in order to assess the inhibitory/bactericidal effect against Leuconostoc mesenteroides MS1. It has been found that the essential oils obtained from Citrus lemon peels and Aloysia polystachya, Eucalyptus cinerea and Laurus nobilis leaves can be used as bactericides against the growth of Leuconostoc mesenteroides MS1. In addition, it has been found that eugenol/sunflower oil concentrations greater than $18.5 \% \mathrm{w} / \mathrm{w}, 0.75 \% \mathrm{w} / \mathrm{w}$ salicylic acid, $0.75 \% \mathrm{w} / \mathrm{w}$ hydroquinone; and Just commercial essential oils of lavender, peppermint and geranium also presented a bactericidal effect against it. These natural extracts used as natural antimicrobials represent an alternative to common chemical food preservatives against the Leuconostoc mesenteroides MS1 strain.
\end{abstract}

Keywords: Leuconostoc mesenteroides MS1, antimicrobial, essential oil, inhibitor, bactericide, Vienna sausage.

Serra, M. A., Garnero, J. A., Nicolau, V. V. y Andreatta, A. E., 2018. Evaluación de extractos vegetales naturales en la inhibición de Leuconostoc mesenteroides MS1. Agriscientia 35: 51-62.

\section{RESUMEN}

El presente estudio se focaliza en la evaluación de extractos vegetales naturales en la inhibición de bacterias que alteran las salchichas de Viena, cuyo crecimiento se evidencia en el producto envasado al vacío después de dos o tres semanas de almacenamiento refrigerado, lo cual produce hinchazón en los envases. Los diferentes extractos naturales fueron obtenidos mediante extracción con vapor de agua, extracción asistida por microondas y extracción asistida por ultrasonido. Además, se evaluaron aceites esenciales comerciales, 
compuestos puros presentes en el reino vegetal y soluciones. Para cada uno de los extractos se realizaron ensayos de sensibilidad microbiana para evaluar el efecto inhibitorio/bactericida contra Leuconostoc mesenteroides MS1. Se ha encontrado que los aceites esenciales obtenidos de cáscaras de Citrus lemon y de hojas de Aloysia polystachya, Eucalyptus cinerea y Laurus nobilis, pueden ser utilizados como potenciales bactericidas contra el crecimiento de Leuconostoc mesenteroides MS1. Además, concentraciones de eugenol/aceite de girasol mayores a $18.5 \% \mathrm{p} / \mathrm{p}$, ácido salicílico $0.75 \% \mathrm{p} / \mathrm{p}$, hidroquinona $0.75 \% \mathrm{p} / \mathrm{p}$; aceites esenciales comerciales Just de lavanda, menta y geranio presentaron efectos bactericidas contra la misma. Estos extractos naturales utilizados como antimicrobianos naturales representan una alternativa a los conservantes comunes de alimentos de síntesis química contra la cepa Leuconostoc mesenteroides MS1.

Palabras clave: Leuconostoc mesenteroides MS1, antimicrobiano, aceite esencial, inhibidor, bactericida, salchicha de Viena.

Serra, M. A., Garnero, J. A., Nicolau, V. V. and Andreatta, A. E.: Universidad Tecnológica Nacional, Facultad Regional San Francisco. CONICET. Av. de la Universidad 501. 2400. San Francisco. Córdoba. Argentina.Correspondence to: aandreatta@sanfrancisco.utn.edu.ar

\section{INTRODUCTION}

It is of interest to prevent the growth of heterofermentative bacteria of the Leuconostoc genus, particularly Leuconostoc mesenteroides, and their undesirable effects on meat products. Different methods can be listed for the inhibition of this bacterial growth: the use of bactericidal microorganisms, the use of technological processes and the use of additives. In general, the species of the Leuconostoc genus grow rapidly since their metabolism is energy efficient. This has a significant influence on $\mathrm{pH}$ reduction, milky exudate production and sour odor development. The growth of these bacteria is related to the appearance of certain volatile compounds such as aldehydes and organic acids (Diez, Jaime and Rovira, 2009).

Regarding the use of bactericidal microorganisms in vacuum packed meat products, the strain Lactobacillus sakei $10 \mathrm{~A}$, with homofermentative metabolism, has been observed to inhibit the growth of $L$. mesenteroides, among other heterofermentative bacteria (Vermeiren, Devlieghere, Vandekinderen, Rajtak and Debevere, 2006).

Concerning the use of technological processes such as the application of high pressures and pasteurization, it has extended the shelf life of meat products by reducing the population of $L$. mesenteroides (Diez et al., 2009). Besides, the use of Pediocin $\mathrm{AcH}$ combined with a hydrostatic pressure $(345 \mathrm{MPa})$ and a high temperature $\left(50^{\circ} \mathrm{C}\right)$ has shown a high synergism in the viability reduction of this microorganism (Kalchayanand, Sikes, Dunne and Ray, 1998).

As regards the use of additives, it has been observed that the addition of organic salts results in a more extended product shelf life (Diez et al., 2009). In this regard, the influence of $\mathrm{pH}$ and temperature on bactericidal production and growth against the strain L. mesenteroides L124 was assessed by Mataragas, Metaxopoulos, Galiotou and Drosinos (2003). Concerning the work of Blaszyk and Holley (1998), they found that the combination of monolaurin, eugenol and sodium citrate is more effective against the growth of $L$. mesenteroides than each one of the separate components. Gill and Holley (2000), found that lysozyme, nisin and EDTA combination treatments can be used for colonization and growth control for this bacteria, among others. Lozano Rodríguez, Arvizu Medrano, Padilla Frausto, Pérez and Ibarra Vallejo (1992), analyzed the antimicrobial development of $L$. mesenteroides under different combinations of nisin, lactic acid, citric acid, mixtures of nisin and lactic acid; and mixtures of nisin and citric acid. Ángel, Mulet, Cárdenas, Durán and Mejía (2009), established that the salts $\mathrm{CaCl}_{2}, \mathrm{NaClO}$, EDTA, $\mathrm{NaNO}_{2}, \mathrm{Na}_{2} \mathrm{SO}_{3}$ and $\left(\mathrm{NH}_{4}\right)_{3} \mathrm{PO}_{4}$ are good control agents for fermentations caused by L. mesenteroides, and were shown to be efficient in its inhibition.

The use of natural extracts for the inhibition of $L$. mesenteroides is also under study. In this regard, Radha Krishnan et al. (2014), observed the 
inhibitory power of aqueous extracts of Syzygium aromaticum, Cinnamomum cassia, Origanum vulgare and Brassica nigra, and determined the minimum inhibitory concentration to be $15,10,20$ and $25 \mathrm{mg} / \mathrm{mL}$, respectively. Concerning Kivanç, Akgül and Doğan (1991), an inhibitory effect against the growth of $L$. mesenteroides was found with the use of oregano and its essential oils, whereas a stimulation effect was found with the use of cumin. In turn, an inhibitory effect on these strains was found with jasmonic acid, occurring in plants due to the lipoxygenation of linolenic acid (Michelena et al., 2005). Regarding the work of Fernández-López, Zhi, Aleson-Carbonell, Pérez-Alvarez and Kuri (2005), garlic extract (Aquaresin $₫$ garlic), lemon fiber extract and orange fiber extract were shown to produce no inhibition against $L$. mesenteroides subsp. mesenteroides 824 and L. mesenteroides subsp. dextranicum 882. On the contrary, rosemary oil and water extract (Herbalox® Type W), rosemary water extract (Duralox®) and rosemary oil extract (Herbalox® Type HTO) demonstrated inhibition against these two subspecies of $L$. mesenteroides, being the effect of rosemary oil extract the greatest.

The application of natural product extracts as antimicrobials is of particular interest to 'green consumers', mainly because they represent an alternative to common chemical food preservatives and because they have a lower environmental impact (Burt, 2004; Settanni et al., 2012). Besides, the resistance of pathogenic bacteria to classical preservatives and the reduction in salt content in food production promote great interest in alternative antimicrobial agents (Burt, 2004).

Several factors affect the chemical composition of essential oils and their antimicrobial properties (Burt, 2004; Settanni et al., 2014). However, the biological activity of essential oils must be considered as resulting from the occurrence of synergism or antagonism between their several components (Militello et al., 2011). For food applications, it is convenient to study the effectiveness of each essential oil as a natural antimicrobial additive, considering it as a whole ingredient instead of a mixture of components (Militello et al., 2011). The antimicrobial activity of essential oils in food is important when it comes to inhibiting the proliferation of spoilage bacteria populations, as well as reducing them.

The particular aim of this work was to find natural extracts with inhibitory and bactericidal power against $L$. mesenteroides MS1 strain present in vacuum packed Vienna sausages whose growth becomes evident in the vacuum packed product after two to three weeks of refrigerated storage causing packages to swell.

\section{MATERIALS AND METHODS}

\section{Bacteria isolation}

The isolation of spoiling bacteria was carried out using vacuum packed Vienna sausages with visible package swelling as a consequence of the production of gas. The sausage surface was swabbed using sterile swabs. Inoculation was performed into MRS (de Man, Rogosa and Sharpe) broth with Dürham tubes. Incubation was carried out at $30{ }^{\circ} \mathrm{C}$ for $72 \mathrm{~h}$. Cultures of positive tubes, presenting turbidity and gas production, were streaked on MRS agar and then incubated in microaerophilia for $72 \mathrm{~h}$. Afterwards, suspicious colonies were isolated, and the biochemical and molecular typification of the bacterial strains was performed.

\section{Biochemical and molecular typification of the strain}

The biochemical typification of the bacterial strain was carried out following the procedure presented by Mulet, Ledesma, Vanegas and Argote Vega (2010), which includes the following tests: cellular morphology, Gram staining, cellular grouping, carbon dioxide production, dextran production, growth in MRS broth, growth in Mayeux medium, growth in nutrient agar, growth at different temperatures, and growth at different salt concentrations.

Bacterial strain identification was carried out by sequencing a fragment of the gene coding the 16S rRNA (Edwards, Rogall, Blöcker, Emde and Böttger, 1989) at the Instituto de Lactología Industrial, at the Universidad Nacional del Litoral (Santa Fe, Argentina) (Cardamone et al., 2011; Pujato et al., 2014), using the GenElute ${ }^{\mathrm{TM}}$ Bacterial Genomic DNA Kit (Sigma, St. Louis, MO, USA). The strain identity was determined by similitude with available sequences using a comparison of the 'nucleotidenucleotide BLAST' type from the NCBI database (National Center for Biotechnology Information, U.S. National Library of Medicine, 2016).

\section{Natural extracts isolation}

Citrus aurantifolia (lime), Citrus lemon (lemon), Citrus reticulate (mandarin orange), Citrus sinensis (orange), Citrus paradise (grapefruit), Citrullus lanatus (watermelon), Malus domestica (apple) and Cucumis melo (muskmelon) were purchased from shops in the San Justo department, in the province of Córdoba (Argentina). Regarding the Laurus nobilis (laurel), Mentha piperita L. (peppermint), 
Minthostachys verticillata (peperina), Rosmarinus officinalis (rosemary), Aloysia citrodora (lemon verbena or cedrón), Aloysia polystachya (burro), Eucalyptus cinerea and Eucalyptus tereticornis, as well as the Lavandula angustifolia (lavender) were collected in the same geographical area. The Vitis vinifera Tannat (grape) was provided by Nanini S.R.L. winery in the Colón department in the province of Córdoba (Argentina). Dehydrated leaves of Poligonum convolvulus (convolvulus) were purchased under the brand name Suquía and Helianthus annuus (sunflower) seeds under the brand name Sturla.

For the extraction of bioactive compounds from natural products, different techniques were used, such as steam stripping, ultrasound assisted extraction and microwave assisted extraction. In the case of commercial essential oils, no process of purification was required, whereas pure compounds and solutions were diluted. Bioactive compounds extracted from natural products: for the extractions, the vegetal material was ground using a grinder at maximum speed (Moulinex, $750 \mathrm{~W}$ ) for $2 \mathrm{~min}$. (Tables 2 and 3 describe the extraction procedure used for each vegetal material and the part of the plant from which it was taken.) The different extraction techniques are detailed below:

Steam Stripping: The material to be extracted is placed into a stainless steel basket with a $32+$ mesh (0.5 $\mathrm{mm}$ mesh opening) located on the rectifying column, which is coupled to a condenser through which water circulates. The water steam is generated in a $500 \mathrm{~mL}$ round bottom flask with a double purpose: heating the mixture to its boiling point, and lowering the boiling temperature of the volatile components in the vegetal material by adding up the water steam pressure. The steam coming out from the rectifying column is condensed in the condenser, thus separating the water from a denser essential oil. The water returns to the round bottom flask through the lower pipe leaving the decanter, while the oil accumulates in the tube connected to the discharge valve. These tests were performed on $100 \mathrm{~g}$ samples of material, and the equipment was operated for 120 min after boiling started. In the particular case of $C$. lemon, the essential oil obtained by steam stripping was then dried in a Numak (DZF 6051) vacuum drying oven at $30^{\circ} \mathrm{C}$ and $20.2 \mathrm{kPa}$ for $24 \mathrm{~h}$ due to its poor separation from water.

The essential oils with bactericidal nature were later analyzed by gas chromatograph with mass spectrometry detector with the aim to know the composition. Two different methods were used in this characterization:

Method (a): A Perkin Elmer Clarus 500 gas chromatograph with a mass spectrometry detector, with an Elite 5 column (60 m length, $0.25 \mathrm{~mm}$ inner diameter, $0.25 \mu \mathrm{m}$ thickness film) using $\mathrm{H}_{2}$ as carrier gas at $1 \mathrm{~mL} / \mathrm{min}$ of flow rate. The following were the operating conditions: injector temperature, $220^{\circ} \mathrm{C}$; detector temperature, $150{ }^{\circ} \mathrm{C}$; scan mode; ionization energy, $70 \mathrm{eV}$; injected volume, $1 \mu \mathrm{L}$; initial oven temperature, $70^{\circ} \mathrm{C}(0 \mathrm{~min})$; and heating at $4^{\circ} \mathrm{C} / \mathrm{min}$ up to $240^{\circ} \mathrm{C}$ (4.50 min).

Method (b): A Perkin Elmer Clarus 600 gas chromatograph by mass spectrometry with a DB5 Perkin Elmer column (60 m length, $0.25 \mathrm{~mm}$ in inner diameter, $0.25 \mu \mathrm{m}$ thickness film) using helium as carrier gas (49.6 psi, $342 \mathrm{kPa}$ ). The following were the operating conditions: detector temperature, $150{ }^{\circ} \mathrm{C}$; injector temperature, $300^{\circ} \mathrm{C}$; temperature of the GC-MS interface, $250{ }^{\circ} \mathrm{C}$; scan mode; injected volume, $1 \mu \mathrm{L}$; initial oven temperature, $60{ }^{\circ} \mathrm{C}$ (5 min); and heating at $5^{\circ} \mathrm{C} / \mathrm{min}$ up to $240^{\circ} \mathrm{C}$ (10 min). Peak identification was performed by comparison with spectra in the libraries of NIST MS Search Program 2.0.

Ultrasound assisted extraction: To this effect, an ultrasound equipment (Numak ultrasonic cleaner model PS-10 A) was used, where $2 \mathrm{~g}$ of ground material in $5 \mathrm{~mL}$ of distilled water were subjected to $50^{\circ} \mathrm{C}$ for $30 \mathrm{~min}$. Afterwards, the extract was filtered using filter paper (black stripe, $125 \mathrm{~mm}$, Munktell).

Microwave assisted extraction: A Whirlpool microwave oven (model WMD 25 GS) was used, where $2 \mathrm{~g}$ of ground material in $5 \mathrm{~mL}$ of distilled water were subjected to $80 \%$ power for 4 min. Afterwards, the extracts were filtered as with ultrasound assisted extraction using filter paper (black stripe, $125 \mathrm{~mm}$, Munktell).

For all the above extractions, the extracts were kept in vials and were hermetically sealed using a rubber stopper and an aluminum seal.

The total polyphenol content in the extract obtained with ultrasound assisted extraction and microwave assisted extraction was determined using the Folin-Ciocalteu colorimetric method (Ivanova et al., 2011). In this technique, an aliquot of $1 \mathrm{ml}$ of extract was mixed with $5 \mathrm{ml}$ of distilled water and 0.2 $\mathrm{ml}$ of the Folin-Ciocalteu reagent in a test tube and left standing for $3 \mathrm{~min}$. After that, $1.5 \mathrm{ml}$ of sodium carbonate solution was added and it was brought to a final volume of $10 \mathrm{ml}$ with distilled water. The mixture was carried to an ultrasound bath at $50{ }^{\circ} \mathrm{C}$ for 20 minutes. The absorbance of the mixture was measured at $765 \mathrm{~nm}$ using the spectrophotometer. The total phenolic compounds present in the extract were expressed as mg of gallic acid equivalent per mg of vegetal material, and was calculated from a calibration curve of different solutions of gallic acid. 
Just commercial essential oils: Commercial lemon, orange, lavender, geranium and peppermint essential oils, "Swiss Just" (2016), were purchased and used with no further purification.

Solutions and pure compounds: Different concentrations of pure compounds were diluted in distilled water, or in sunflower oil in the particular case of eugenol due to their chemical affinity. The following compounds were used: gallic acid (Biopack, 98\%), ascorbic acid (Cicarelli, >99\%), citric acid (Cicarelli, $>99.5 \%$ ), tartaric acid (Cicarelli, >99\%), succinic acid (Anedra, 99\%), glacial acetic acid (Cicarelli, 99.5\%), salicylic acid (Cicarelli, >99\%), eugenol (Sigma-Aldrich, 99\%), hydroquinone (Mallinckrodt, 99.95\%), camphor (Drosanto, $\geq 96 \%$ ), sorbitol solution (Ingredion, 70\% w/w), R (+) limonene (Fluka, 98\%).

The positive controls were implemented with the commercial antibiotic gatifloxacin (Gatif Forte, Poen, $0.5 \% \mathrm{w} / \mathrm{w}$ ) and its dilutions, which exhibit antibacterial action against a wide range of aerobic Gram positive and Gram negative bacteria; sodium hypochlorite (Ayudín, 2.5\% w/w); and ethyl alcohol (Porta, 96\% w/w). For the negative controls, sunflower oil (AGD SA, Argentina, 100\%) and granulated soy lecithin (Modelife, 70\% w/w) were used.

\section{Sensitivity tests}

The sensitivity tests were carried out on the different natural extracts, commercial essential oils, solutions and pure compounds used as antimicrobials. To this effect, the agar diffusion method was used (Clinical and Laboratory Standards Institute, 2012), where a disc with a known specific amount of antimicrobial was applied to the surface of MRS agar previously inoculated with the L. mesenteroides MS1. The inoculation was prepared following the direct colony suspension method in a saline solution in order to obtain a 0.5 density in the Mc Farland scale, which is approximately equivalent to a $1.5 \times 10^{8} \mathrm{CFU} /$ $\mathrm{mL}$ concentration. The inoculation was made with a swab soaked with this standar dized solution, which was evenly spread on the agarized culture

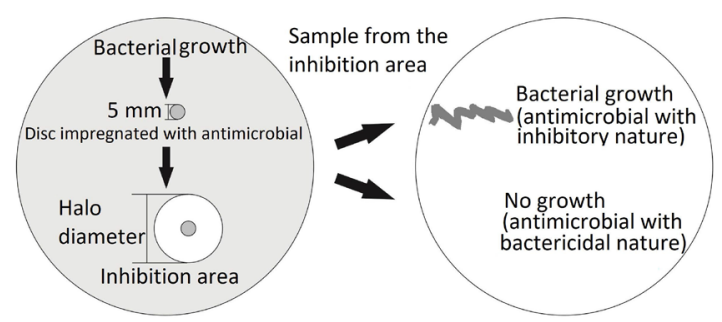

Figure 1. Schematic representation for the steps of sensitivity tests in Petri dishes. medium. The sterile $5 \mathrm{~mm}$ diameter filter paper discs, obtained from black stripe filter paper (125 mm, Munktell), were impregnated with a known amount of the antimicrobial. Afterwards, the Petri dishes were incubated at $30{ }^{\circ} \mathrm{C}$ for $48 \mathrm{~h}$. The antimicrobial could be seen to spread from the disc to the culture medium, producing an inhibition zone in the cases where an inhibitory effect took place. Figure 1, represents the schematic representation for the steps of sensitivity tests in Petri dishes.

In the cases where there was inhibition, the process was continued by taking a sample from the inhibition halo, inoculating it in MRS agar with no antimicrobials, and incubating it at $30{ }^{\circ} \mathrm{C}$ for 48 h. Afterwards, evidence or lack of evidence was observed for the growth of $L$. mesenteroides in the samples, thus determining whether the extract concentrations were bactericidal or inhibitory. When there was no growth, the antimicrobial was considered to be of bactericidal nature. If there was growth, the antimicrobial was considered to be of an inhibitory nature.

\section{Statistical Analysis}

The essential oils with bactericidal nature were subjected to analysis of variance (ANOVA) with a degree of significance lower than $1 \%$ and type 1 error, after verifying the hypothesis for this model by analyzing its residues. In a first test, the average inhibition zone for each essential oil was compared with the reference antibiotic $(0.025 \% \mathrm{w} / \mathrm{w}$ gatifloxacin) by means of Dunnett's test. In this test, the research hypothesis was that the inhibition zone for the test compound was different from the one for the reference antibiotic, against the hypothesis of absence of differences (null hypothesis), which states that there is no significant difference between the inhibition zone for the test compound and the reference antibiotic. In a second test, multiple comparison tests were carried out using Tukey's method in order to identify differences between the essential oils using the same hypothesis as in the previous test. Both tests were carried out using the statistical computing software called 'RStudio', available on line (RStudio, 2018).

\section{RESULTS AND DISCUSSION}

\section{Identification of the bacteria}

The biochemical typification tests indicate that the bacteria under study corresponds to Gram positive, catalase negative, facultative anaerobic, heterofermentative cocci, glucose type 4 , forming 
pairs and chains; producing ethanol, carbon dioxide, dextran, and lactate, with negative reaction to growth at $45{ }^{\circ} \mathrm{C}$, of negative dissimilation to arginine, not mobile and non-spore forming. The selective medium used to cultivate the bacteria was MRS, with an optimum growth at $30^{\circ} \mathrm{C}$ for a 24-48 $\mathrm{h}$ period. Besides, growth was observed in a Ma-yeux medium (Mulet et al., 2010) and in a nutrient medium. The growth was positive in MRS broth with $3 \% \mathrm{w} / \mathrm{w} \mathrm{NaCl}$ and negative with $10 \% \mathrm{w} / \mathrm{w}$ $\mathrm{NaCl}$.

With the identification of microorganisms by sequencing a fragment of the gene coding the $16 \mathrm{~S}$ rRNA (oval cocci chains producing gas in MRS at $34^{\circ} \mathrm{C}$ ), the isolate was identified as belonging to the $L$. mesenteroides species with a high degree of certainty. However, the subspecies (mesenteroides or dextranicum) could not be distinguished with the technique applied. This is concordant with the research by Samelis and Georgiadou (2000), who also found considerable presence mainly of $L$. mesenteroides subsp. mesenteroides in air stored taverna sausages.

\section{Inhibitory effect of antimicrobials}

After the identification of the bacteria under study L. mesenteroides MS1, sensitivity tests were performed on extracts obtained from dried leaves of $L$. nobilis, E. cinerea, E. tereticornis, M. piperita L., M. verticillata, $R$. officinalis, $A$. citrodora, $P$. convolvulus, A. polystachya; from fresh peels of C. aurantifolia, C. lemon, C. reticulate, C. sinensis, $C$. paradisi; from dried flowers of $L$. angustifolia and from dried seeds of $H$. annuus, C. lemon, $C$. sinensis, $C$. lanatus, $V$. vinifera Tannat, $C$. melo and M. domestica.

Besides, the antimicrobial effect was analyzed in solutions of citric acid, gallic acid, salicylic acid, succinic acid, tartaric acid, acetic acid, ascorbic acid, hydroquinone, eugenol, sorbitol, commercial essential oils of lavender, peppermint, geranium, lemon and orange, and pure compounds such as camphor and limonene.

In Table 1, positive controls (commercial antibiotic gatifloxacin, sodium hypochlorite and ethyl alcohol); as well as negative controls (sunflower oil and soy lecithin) are shown.

In Table 2, the sensitivity tests are shown for the different antimicrobials with negative inhibition results, indicating the mg range used for each antimicrobial. For these cases, at least three concentrations were tested within the indicated range. It can be seen that no inhibitory effect was observed in the aqueous extracts obtained with microwave assisted or ultrasound assisted extraction processes. Said extracts feature a total polyphenol content ranging from $0.13 \mathrm{mg}$ gallic acid equivalent $/ \mathrm{g}$ of sample for the $C$. sinensis seed extract, up to $2.3 \mathrm{mg}$ gallic acid equivalent/g of sample for the aqueous extract of $P$. convolvulus, both of them obtained by means of microwave assisted extraction. The $\mathrm{pH}$ values presented in the entire Table 2 are acid and range between 2.8 and 6.7.

The antimicrobials with positive inhibition results presented in Table 3 were subsequently subjected to inoculations from the inhibition halos on a second plate with agarized MRS medium, as described

Table 1. Positive and negative controls against $L$. mesenteroides MS1

\begin{tabular}{|c|c|c|c|c|c|}
\hline Antimicrobial agent & Concentration & $\begin{array}{l}\text { Antimicrobial amount } \\
(\mathrm{mg})\end{array}$ & $\begin{array}{c}\text { Halo } \\
\text { diameter } \\
(\mathrm{mm})\end{array}$ & $\begin{array}{c}\mathrm{mm} / \mathrm{mg} \text { of } \\
\text { extract }\end{array}$ & $\mathrm{pH}$ \\
\hline Positive control & $\% \mathrm{w} / \mathrm{w}$ & & & & \\
\hline \multirow[t]{9}{*}{ Gatifloxacin } & 0.025 & 13.5 & 38 & 2.81 & 7.0 \\
\hline & & 15.9 & 40 & 2.52 & \\
\hline & & 29.1 & 40 & 1.37 & \\
\hline & 0.25 & 9.7 & 42 & 4.32 & 7.0 \\
\hline & & 42.1 & 47 & 1.12 & \\
\hline & & 57.0 & 49 & 0.86 & \\
\hline & 0.5 & 12.2 & 40 & 3.28 & 7.0 \\
\hline & & 14.5 & 45 & 3.10 & \\
\hline & & 23.0 & 50 & 2.17 & \\
\hline Sodium hypochlorite & 2.5 & 13.3 & 18 & 1.35 & 10.0 \\
\hline Ethanol & 96 & 29.8 & 7 & 0.23 & 6.7 \\
\hline Negative control & $\% \mathrm{w} / \mathrm{w}$ & & & & \\
\hline Sunflower oil & 100 & 11.3 & n.d. & & 5.0 \\
\hline Soy lecithin & 2 & 18.7 & n.d. & & 6.0 \\
\hline
\end{tabular}


Table 2. Essential oils, aqueous extracts, solutions, commercial essential oils and pure compounds not inhibiting $L$. mesenteroides MS1

\begin{tabular}{lccc}
\hline Antimicrobial & From & $\begin{array}{c}\text { mg of } \\
\text { extract per } \\
\text { disc }\end{array}$ & pH \\
\hline Essential oils obtained by steam stripping \\
C. aurantifolia & Fresh peels & $5.5-20.9$ & 5.0 \\
C. paradisi & Fresh peels & $7.7-9.0$ & 5.0 \\
C. reticulate & Fresh peels & $9.9-14.9$ & 5.0 \\
C. sinensis & Fresh peels & $7.7-14.8$ & n.q. \\
E. cinerea & Dried leaves & $1.6-6.0$ & 5.0 \\
E. tereticornis & Dried leaves & $4.4-13.0$ & n.q. \\
L. angustifolia & Dried leaves & $11.5-15.2$ & 5.0 \\
L. nobilis & Dried leaves & $7.5-11.1$ & 5.0 \\
M. piperita L. & Dried leaves & $13.9-27.8$ & 5.0 \\
M. verticillata & Dried leaves & $10.8-24.2$ & n.q. \\
R. officinalis & Dried leaves & $6.2-9.8$ & n.q. \\
Aqueous extract obtained by microwave & \\
assisted extraction & & & \\
A. citrodora & Dried leaves & $16.4-24.1$ & 6.4 \\
C. lanatus & Dried seeds & $7.9-33.7$ & 6.4 \\
C. lemon & Dried seeds & $5.5-13.4$ & 4.2 \\
C. sinensis & Dried seeds & $10.4-64.8$ & 5.1 \\
H. annuus & Dried seeds & $23.7-75.4$ & 6.0 \\
P. convolvulus & Dried leaves & $11.1-43.4$ & 4.8 \\
V. vinifera Tannat & Dried seeds & $18.3-26.2$ & 4.6 \\
Aqueous extactobtained by utrasound & &
\end{tabular}

\section{Aqueous extract obtained by ultrasound} assisted extraction

\begin{tabular}{lccc} 
C. lemon & Fresh peels & $14.5-33.3$ & 4.3 \\
C. melo & Dried seeds & $8.4-15.7$ & 6.7 \\
M. domestica & Dried seeds & $3.8-18.9$ & 5.8 \\
V. vinifera Tannat & $\begin{array}{c}\text { Dried seeds } \\
\text { Concentration }\end{array}$ & $3.7-15.2$ & 4.6 \\
Solutions & (\%w/w) & & \\
Acetic acid & 0.60 & $21.8-26.1$ & 4.0 \\
Ascorbic acid & 0.75 & $16.0-43.4$ & 2.9 \\
Citric acid & 0.75 & $16.8-19.1$ & 2.5 \\
Eugenol/sunflower oil & 6.9 & $11.4-14.5$ & 5.0 \\
Eugenol/sunflower oil & 12.5 & $3.3-5.3$ & 5.0 \\
Eugenol/sunflower oil & 18.5 & 3.1 & 5.0 \\
Gallic acid & 0.75 & $14.7-21.1$ & 3.0 \\
Salicylic acid & 0.75 & 3.5 & 2.8 \\
Sorbitol & 70.0 & $19.2-26.8$ & 5.0 \\
Succinic acid & 0.75 & $40.5-42.4$ & 2.8 \\
Tartaric acid & 0.75 & $9.2-60.3$ & 2.4 \\
Commercial essential oils & & & \\
Lemon essential oil & Just commercial & $5.1-15.2$ & 6.0 \\
Orange essential oil & Just commercial & $8.2-15.5$ & 6.0 \\
Pure compounds & & & \\
Camphor & & $1.0-8.3$ & n.q. \\
Limonene & & $8.5-9.6$ & 5.0 \\
\hline n.q.not & & &
\end{tabular}

n.q.: not quantified above in Sensitivity tests. From this, it could be observed that these antimicrobials featured a bactericidal concentration, since no growth of L. mesenteroides MS1 was exhibited in this second inoculation. Table 3 , also contains the $\mathrm{mg}$ used in the disc for each antimicrobial agent, the diameter of the inhibition halo produced, the ratio between the inhibition diameter and the amount of antimicrobial used and the acidity value for the extract used.

C. lemon, A. polystachya, E. cinerea and L. nobilis essential oils, eugenol/sunflower oil concentrations greater than $18.5 \% \mathrm{w} / \mathrm{w}, 0.75 \%$ w/w salicylic acid, $0.75 \% \mathrm{w} / \mathrm{w}$ hydroquinone and commercial essential oils of lavender, peppermint and geranium presented bactericidal effects against L. mesenteroides MS1. Again, the $\mathrm{pH}$ values for these antimicrobials are acid, and range between 2.8 and 6 .

Based on an exploratory analysis performed on the data from Table 3, it can be stated that the ave-rage diameters of the inhibition zone for each essential oil are different from each other.

\section{Characterization of the extracts with bacterici-dal effect}

Although it is convenient to study the effectiveness of each essential oil as a natural antimicrobial additive by considering it as a whole ingredient instead of a mixture of components (Militello et al., 2011) it is also important to know its constituting compounds. In this regard, the identification of the compounds in the essential oils with bactericidal effect was performed through gas chromatography by mass spectrometry.

In the particular analyses of the L. nobilis and E. cinerea essential oils, the identification of their components by GC-MS was using the Method (a), meanwhile the analyses of the $C$. lemon and A. polystachya essential oils was employing the Method b) described in Natural extracts isolation. These results are presented in Table 4 and 5 respectively.

The main compounds in the E. cinerea essential oil are: 1,8-cineole (84.17\%), $\alpha$-pinene $(8.18 \%)$, $\alpha$-terpineol acetate $(4.51 \%)$ and $\alpha$-terpineol $(1.46 \%)$ (Table 4). Also, in Table 4, it can be observed that $L$. nobilis essential oil features a high content of 1,8-cineole (46.26\%), linalool $(22.7 \%)$, $\beta$-pinene (9.57\%), and $\alpha$-terpineol acetate $(7.68 \%)$, while its contents are lower regarding eugenol and its derivatives, $\alpha$-phellandrene, terpinene 4 -ol, and $\alpha$-terpineol, among others. The limonene (68.29\%), $\beta$-pinene $(5.07 \%)$ and $\gamma$-terpinene $(5.86 \%)$ are the main components of $C$. lemon essential oil while 
carvone $(90.2 \%)$ and limonene $(9.14 \%)$ are the main components of $A$. polystachya essential oil (Table 5).

The following are the compositions of Just commercial oils as stated by the manufacturer: for the lavender essential oil, coumarin, farnesol, geraniol, 7-methoxycoumarin, 1-octen-3-yl acetate; for geranium essential oil, citral, eugenol, farnesol,

Table 3. Antimicrobials with bactericidal effect against $L$. mesenteroides MS1

\begin{tabular}{|c|c|c|c|c|c|}
\hline Antimicrobial & From & $\begin{array}{c}\text { Amount of } \\
\text { extract }(\mathrm{mg})\end{array}$ & $\begin{array}{c}\text { Halo diameter } \\
\text { (mm) }\end{array}$ & $\begin{array}{c}\mathrm{mm} / \mathrm{mg} \text { of } \\
\text { extract }\end{array}$ & $\mathrm{pH}$ \\
\hline \multicolumn{6}{|c|}{ Essential oils obtained by steam stripping } \\
\hline \multirow[t]{3}{*}{ L. nobilis } & Dried leaves & 12.2 & 12 & 0.98 & 5.0 \\
\hline & & 13.7 & 13 & 0.95 & \\
\hline & & 17.0 & 14 & 0.82 & \\
\hline \multirow[t]{5}{*}{ C. lemon } & Fresh peels & 5.3 & 6 & 1.13 & 5.0 \\
\hline & & 8.0 & 7 & 0.88 & \\
\hline & & 9.4 & 7 & 0.74 & \\
\hline & & 10.3 & 8 & 0.78 & \\
\hline & & 15.8 & 10 & 0.63 & \\
\hline \multirow[t]{7}{*}{ A. polystachya } & Dried leaves & 9.6 & 8 & 0.83 & 5.0 \\
\hline & & 10.2 & 9 & 0.88 & \\
\hline & & 11.8 & 10 & 0.85 & \\
\hline & & 12.1 & 12 & 0.99 & \\
\hline & & 14.2 & 18 & 1.27 & \\
\hline & & 16.8 & 20 & 1.19 & \\
\hline & & 17.7 & 21 & 1.19 & \\
\hline \multirow[t]{4}{*}{ E. cinerea } & Leaves & 6.8 & 8 & 1.18 & 5.0 \\
\hline & & 8.9 & 12 & 1.35 & \\
\hline & & 11.4 & 14 & 1.23 & \\
\hline & & 15.2 & 15 & 0.99 & \\
\hline Solutions & Concentration (\%w/w) & & & & \\
\hline \multirow[t]{2}{*}{ Salicylic acid } & 0.75 & 17.4 & 6 & 0.34 & 2.8 \\
\hline & & 30.0 & 6 & 0.20 & \\
\hline \multirow[t]{3}{*}{ Hydroquinone } & 0.75 & 27.8 & 24 & 0.86 & 5.0 \\
\hline & & 31.2 & 26 & 0.83 & \\
\hline & & 57.1 & 28 & 0.49 & \\
\hline \multirow[t]{2}{*}{ Eugenol/sunflower oil } & 18.5 & 17.4 & 6 & 0.34 & 5.0 \\
\hline & & 29.9 & 6 & 0.20 & \\
\hline \multirow[t]{3}{*}{ Eugenol/sunflower oil } & 29.7 & 4.3 & 23 & 5.35 & 5.0 \\
\hline & & 23.4 & 25 & 1.06 & \\
\hline & & 34.9 & 28 & 0.80 & \\
\hline \multicolumn{6}{|c|}{ Commercial essential oils } \\
\hline \multirow[t]{4}{*}{ Lavender essential oil } & Just commercial & 6.5 & 8 & 1.23 & 6.0 \\
\hline & & 10.6 & 10 & 0.94 & \\
\hline & & 11.7 & 13 & 1.11 & \\
\hline & & 11.8 & 14 & 1.18 & \\
\hline \multirow[t]{4}{*}{ Peppermint essential oil } & Just commercial & 6.1 & 14 & 2.29 & 6.0 \\
\hline & & 9.1 & 20 & 2.19 & \\
\hline & & 9.7 & 21 & 2.16 & \\
\hline & & 12.1 & 22 & 1.81 & \\
\hline \multirow[t]{4}{*}{ Geranium essential oil, } & Just commercial & 5.7 & 20 & 3.50 & 6.0 \\
\hline & & 8.3 & 23 & 2.77 & \\
\hline & & 9.4 & 24 & 2.55 & \\
\hline & & 11.9 & 33 & 2.77 & \\
\hline
\end{tabular}

(Disc diameter: $5 \mathrm{~mm}$; included) 
geraniol, limonene, linalool and for peppermint essential oil, trans-2 hexenol.

In the review by Burt (2004), several works are listed which consider that essential oils obtained from natural products are slightly more effective against Gram positive bacteria than for Gram negative ones. However, not all the studies conclude that Gram positive bacteria are more susceptible (Wilkinson, Hipwell, Ryan and Cavanagh, 2003).

In Figure 2, a comparison is made between the inhibition diameters and the amount of antimicrobial used considering essential oils of C. lemon, A. polystachya, E. cinerea and L. nobilis, $18.5 \%$ $\mathrm{w} / \mathrm{w}$ and $29.7 \% \mathrm{w} / \mathrm{w}$ concentrations of eugenol/ sunflower oil, together with the positive control of gatifloxacin antibiotic at $0.025 \% \mathrm{w} / \mathrm{w}$. It can be observed that, although the effect of the essential oils and the concentrations of eugenol/sunflower oil are lower compared with the antibiotic, the bactericidal

Table 4. Percent composition of E. cinerea and L. nobilis essential oils obtained through gas chromatography by mass spectrometry

\begin{tabular}{|c|c|c|c|}
\hline Retention & Comnound & E. cinere & nobilis \\
\hline time & compound & $\%$ & $\%$ \\
\hline 6.4 & $\alpha$-thujene & & 0.34 \\
\hline 6.6 & $\alpha$-pinene & 8.18 & \\
\hline 7.0 & Camphene & 0.06 & 0.55 \\
\hline 7.5 & $\beta$-pinene & 0.14 & 9.57 \\
\hline 7.7 & Geranyl bromide & 0.10 & \\
\hline 7.8 & Myrcene & & 0.38 \\
\hline 8.3 & $\alpha$-phellandrene & 0.18 & 3.63 \\
\hline 8.6 & 1-hexen-3-yne. 2-tert-butyl- & & 0.40 \\
\hline 8.8 & m-cymene & & 0.32 \\
\hline 9.0 & Limonene & & 1.13 \\
\hline 9.1 & 1,8-cineole & 84.17 & 46.26 \\
\hline 9.7 & $\gamma$-terpinene & 0.18 & 0.66 \\
\hline 10.1 & 5-methyl 1,5-hexadien 3-ol & & 0.15 \\
\hline 10.5 & Ocimene & & 0.16 \\
\hline 10.5 & Terpinolene & 0.05 & \\
\hline 11.0 & Valeric acid, pentyl ester & 0.07 & \\
\hline 11.0 & Linalool & & 22.70 \\
\hline 12.4 & Trans-pinocarveol & 0.20 & \\
\hline 13.7 & Terpinene 4-ol & & 1.74 \\
\hline 13.9 & Perillyl alcohol & 0.48 & \\
\hline 14.3 & $\alpha$-terpineol & 1.46 & 2.76 \\
\hline 15.6 & 5-tetradecen-3-yne (E)- & & 0.14 \\
\hline 16.9 & Isobornyl formate & & 0.23 \\
\hline 17.9 & Methyl geranate & 0.12 & \\
\hline 18.8 & $\alpha$-terpineol & & 0.31 \\
\hline 18.8 & $\alpha$-terpineol acetate & 4.51 & 7.68 \\
\hline 19.0 & Eugenol & & 0.09 \\
\hline 20.4 & Eugenol methyl ether & & 0.64 \\
\hline 21.3 & $\beta$-caryophyllene & 0.09 & 0.17 \\
\hline
\end{tabular}

Table 5. Percent composition of $C$. lemon and A. polystachya essential oils obtained through gas chromatography by mass spectrometry

\begin{tabular}{clcc}
\hline T min & Component & $\begin{array}{c}\text { C. lemon } \\
\%\end{array}$ & $\begin{array}{c}\text { A. polystachya } \\
\%\end{array}$ \\
\hline 10.4 & $\alpha$-pinene & 0.65 & 0.1 \\
11.8 & d-3-carene & 0.47 & \\
12.1 & $\beta$-pinene & 5.07 & 0.1 \\
12.4 & Beta-myrcene & 1.28 & 0.12 \\
14.5 & Limonene & 68.29 & 9.04 \\
15.2 & $\gamma$-terpinene & 5.86 & \\
16.0 & $\alpha$-terpinolene & 0.29 & \\
16.5 & $\beta$-linalool & & 0.1 \\
19.9 & Bergamiol & 4.24 & \\
19.9 & $\alpha$-terpineol & & 0.14 \\
20.8 & Neral & 0.98 & \\
21.6 & Carvone & & 90.2 \\
22.1 & Geranial & 0.68 & \\
23.0 & Not identified & 2.45 & \\
23.5 & (Z.E)- $\alpha$-farnesene & 3.58 & \\
26.8 & $\beta$-caryophyllene & 5.66 & 0.2 \\
28.9 & $\alpha$-curcumene & 0.50 & \\
\hline
\end{tabular}

effects featured by these natural antimicrobials are promising.

By observing Figure 2, it can be confirmed that there is no clear differentiation between the inhibition halo diameter of the essential oils of $C$. lemon, A. polystachya, E. cinerea and L. nobilis with the amount of antimicrobial per disk. Essential oils of L. nobilis, C. lemon, E. cinerea and A. polystachya were subjected to variance test analysis after verifying the hypothesis for this model by analyzing its residues. From the statistical analyses, it could be confirmed that the halo diameters of the antimicrobials used (essential oils of $C$. lemon, A. polystachya, E. cinerea and L. nobilis ) have significant

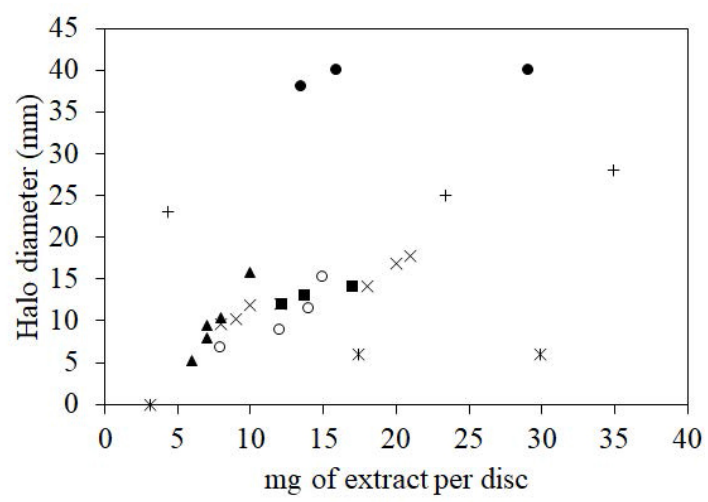

Figure 2. Comparison between the inhibition diameters and the amount of extract for essential oils of: $\Delta C$. lemon, $\times$ A. polystachya, O E. cinerea, $L$. nobilis, * $18.5 \% \mathrm{w} / \mathrm{w}$ eugenol/sunflower oil, $+29.7 \% \mathrm{w} / \mathrm{w}$ eugenol/sunflower oil and the antibiotic $\bullet 0.025 \%$ w/w gatifloxacin 
differences compared to the diameters obtained from the antibiotic used as a reference for these tests. In this sense, the halo diameter obtained from the antibiotic is bigger than those obtained from the essential oils. It could also be concluded that the average diameters of these bactericidal essential oils have no significant differences between each other.

On the other hand, the bactericidal activity herein described for these antimicrobial agents was also found to be effective against other bacteria, as detailed below.

Akgül, Kivanç and Bayrak (1989), found antimicrobial activity in $L$. nobilis essential oil against Enterobacter aerogenes and Streptococcus faecalis strains with $0.05 \%$ and $0.1 \%$ concentrations, respectively. Also et al (1993), found a bactericidal effect in 1:2 dilutions of $L$. nobilis essential oil against Gram positive bacteria such as $S$. faecalis, Staphylococcus aureus, Micrococcus luteus and Bacillus subtilis; and against Gram negative bacteria such as Escherichia coli, Hafnia alvei and Proteus vulgaris.

For lemon essential oils, it has been found that commercial lemons as reported by Settanni et al. (2012), featured some antagonic properties against Listeria monocytogenes and S. aureus, and no antimicrobial activity against Salmonella; although these authors demonstrated that this activity was lower than with other lemon species such as C. lemon (cv. Femminello) cultivated in Sicily (Italy). Besides, in the work by Alfonzo et al. (2017), it was found that the addition of lemon essential oil to salted sardines produced low concentrations of pathogenic and spoilage microorganisms during all the sardine maturation period. Regarding Fisher and Phillips (2006), they demonstrated that lemon essential oil features antimicrobial activity against L. monocytogenes, S. aureus, Bacillus cereus, E. coli $\mathrm{O} 157$ and Campylobacter jejuni. They also verified that lemonene, the main component of this essential oil, features no antibacterial activity, while linalool features high antibacterial activity against these microorganisms. It has also been found that Turkish and Indian lemon essential oil (Al-jabri and Hossain, 2014), in certain concentrations features inhibition against $S$. aureus, E. coli, Pseudomonas aeruginosa and $P$. vulgaris. This negative bioactivity of limonene against $L$. mesenteroides MS1 could also be identified in this study in a concentration range of 8.5-9.6 mg of extract per disc (Table 2).

No antimicrobial activity against any type of bacteria has been reported for the A. polystachya essential oil. As regards the Eucalyptus spp. essential oil, it has antibacterial, fungicidal, antiseptic and pest control properties (Batish, Singh, Kohli and Kaur, 2008).

Considering pure compound solutions, eugenol diluted with sunflower oil features antimicrobial activity, even with small amounts of this component. Eugenol is the main component of clove oil (S. aromaticum). Other researchers assert antimicrobial activity for this compound against $B$. Cereus (Thoroski, Blank and Biliaderis, 1989) and against E. coli, S. typhimurium and L. monocytogenes, V. vulnificus (Kim, Marshall and Wei, 1995) and Salmonella typhi (Devi, Nisha, Sakthivel and Pandian, 2010).

Hydroquinone is present in blueberries, coffee, wheat derivatives, beer, wine, tea, asparagus, pear, and broccoli. Jyoti et al. (2016), also mention that hydroquinone is found in large quantities in marine organisms such as brown algae. These authors extracted hydroquinone and ursolic acid from Artemisia capillaris extracts, which were effective against Mycobacterium tuberculosis.

Salicylic acid was first extracted from the bark of white willows (Salix alba). Also, the black poplar (Populus nigra), cashew (Anacardium occidentale), pumpkin (Cucurbita pepo L.), chamomile (Matricaria chamomilla L.), strawberry (Fragaria vesca L.), tea (Camellia sinensis), etc. are rich in this compound. Grzybowska et al. (2007), determined the minimum inhibitory concentration for disinfectants and antiseptics, salicylic acid among them, for Gram negative and Gram positive bacteria.

Just commercial essential oils of lavender, peppermint and geranium have shown effectiveness against L. mesenteroides MS1. In this regard, Teixeira et al., (2013), analyzed the antimicrobial activity of commercial essential oils of basil, carrot seed, celery seed, citronella, clove, coriander, garlic, grapefruit, lemon, marjoram, onion, origanum, parsley, rosemary, sage, tarragon and thyme purchased from Sigma-Aldrich.

\section{CONCLUSIONS}

Essential oils and aqueous extracts obtained from renewable natural products, pure compounds, solutions and commercial essential oils were assessed in the search for inhibitors/bactericides against the strain L. mesenteroides MS1, present in vacuum packed Vienna sausages after two to three weeks of refrigerated storage.

From the sensitivity tests performed in this research, it can be concluded that, C. lemon, A. polystachya, E. cinerea and L. nobilis essential oils, 
eugenol/sunflower oil concentrations greater than $18.5 \% \mathrm{w} / \mathrm{w}, 0.75 \% \mathrm{w} / \mathrm{w}$ salicylic acid, $0.75 \% \mathrm{w} / \mathrm{w}$ hydroquinone and Just commercial essential oils of lavender, peppermint and geranium presented bactericidal effects against $L$. mesenteroides MS1.

Statistic results confirm that the halo diameters for the antimicrobials used (essential oils of $C$. lemon, A. polystachya, E. cinerea and L. nobilis) have significant differences compared to the diameters obtained for the antibiotic used as a reference for these tests $(0.025 \% \mathrm{w} / \mathrm{w}$ gatifloxacin) and that the average diameters for these essential oils have no significant differences between each other.

With this research, it can be verified that these natural extracts used as natural antimicrobials represent an alternative to common chemical food preservatives against L. mesenteroides MS1. Further studies will lead to the determination of the minimum inhibitory concentrations and the minimum bactericidal concentrations for each one of the extracts herein identified.

\section{ACKNOWLEDGEMENTS}

The authors wish to thank Universidad Tecnológica Nacional (UTN, PID 3486 and PID 3458), and the Consejo Nacional de Investigaciones Científicas y Tecnológicas (CONICET, PIP 0941), both from Argentina, for funding this work. Besides, the company La Piamontesa is acknowledged for providing the bacteria under studio.

\section{REFERENCES}

Akgül, A., Kivanç, M. and Bayrak, A. (1989). Chemical Composition and Antimicrobial Effect of Turkish Laurel Leaf Oil. JEOR, 1 (6), 277-280.

Alfonzo, A., Martorana, A., Guarrasi, V., Barbera, M., Gaglio, R., Santulli, A., Settani, L., Galati, A., Moschetti, G. and Francesca, N. (2017). Effect of the lemon essential oils on the safety and sensory quality of salted sardines (Sardina pilchardus Walbaum 1792). Food Control, 73, Part B, 1265-1274.

Al-jabri, N. N., and Hossain, M. A. (2014). Comparative chemical composition and antimicrobial activity study of essential oils from two imported lemon fruits samples against pathogenic bacteria. Beni-Suef University Journal of Basic and Applied Sciences, 3 (4), 247-253.

Ángel, J., Mulet, R. C., Cárdenas, H., Durán, J. A. and Mejía, L. F. (2009). Efecto de las concentraciones salinas en la inhibición de Leuconostoc mesenteroides en un ingenio azucarero. Revista Científica Guillermo de Ockham, 7 (1), 13-18.
Batish, D. R., Singh, H. P., Kohli, R. K. and Kaur, S. (2008). Eucalyptus essential oil as a natural pesticide. Forest Ecology and Management, 256 (12), 2166-2174.

Biondi, D., Cianci, P., Geraci, C., Ruberto, G. and Piattelli, M. (1993). Antimicrobial activity and chemical composition of essential oils from sicilian aromatic plants. Flavour and Fragrance Journal, 8 (6), 331-337.

Blaszyk, M. and Holley, R. A. (1998). Interaction of monolaurin, eugenol and sodium citrate on growth of common meat spoilage and pathogenic organisms. International Journal of Food Microbiology, 39 (3), 175-183.

Burt, S. (2004). Essential oils: their antibacterial properties and potential applications in foods-a review. International Journal of Food Microbiology, 94(3), 223-253.

Cardamone, L., Quiberoni, A., Mercanti, D. J., Fornasari, M. E., Reinheimer, J. A. and Guglielmotti, D. M. (2011). Adventitious dairy Leuconostoc strains with interesting technological and biological properties useful for adjunct starters. Dairy Science Technology, 91(4), 457470.

Clinical and Laboratory Standards Institute. (2012). Performance Standards for Antimicrobial Disk Susceptibility Tests (M02-A11); Approved Standard-Eleventh Edition.

Devi, K. P., Nisha, S. A., Sakthivel, R. and Pandian, S. K. (2010). Eugenol (an essential oil of clove) acts as an antibacterial agent against Salmonella typhi by disrupting the cellular membrane. Journal of Ethnopharmacology, 130(1), 107-115.

Diez, A. M., Jaime, I. and Rovira, J. (2009). The influence of different preservation methods on spoilage bacteria populations inoculated in morcilla de Burgos during anaerobic cold storage. International Journal of Food Microbiology, 132(2-3), 91-99.

Edwards, U., Rogall, T., Blöcker, H., Emde, M. and Böttger, E. C. (1989). Isolation and direct complete nucleotide determination of entire genes. Characterization of a gene coding for $16 \mathrm{~S}$ ribosomal RNA. Nucleic Acids Research, 17(19), 7843-7853.

Fernández-López, J., Zhi, N., Aleson-Carbonell, L., PérezAlvarez, J. A. and Kuri, V. (2005). Antioxidant and antibacterial activities of natural extracts: Application in beef meatballs. Meat Science, 69(3), 371-380.

Fisher, K. and Phillips, C. A. (2006). The effect of lemon, orange and bergamot essential oils and their components on the survival of Campylobacter jejuni, Escherichia coli $\mathrm{O} 157$, Listeria monocytogenes, Bacillus cereus and Staphylococcus aureus in vitro and in food systems. Journal of Applied Microbiology, 101, 12321240.

Gill, A. O. and Holley, R. A. (2000). Inhibition of bacterial growth on ham and bologna by lysozyme, nisin and EDTA. Food Research International, 33(2), 83-90.

Grzybowska, W., Młynarczyk, G., Młynarczyk, A., Bocian, E., Luczak, M. and Tyski, S. (2007). Estimation of ac- 
tivity of pharmakopeal disinfectants and antiseptics against Gram negative and Gram positive bacteria isolated from clinical specimens, drugs and environment. Medycyna Doswiadczalna I Mikrobiologia, 59(1), 65-73

Ivanova, V., Dörnyei, Á., Márk, L., Vojnoski, B., Stafilov, T., Stefova, M. and Kilár, F. (2011). Polyphenolic content of Vranec wines produced by different vinification conditions. Food Chemistry, 124(1), 316-325

Jyoti, M. A., Nam, K. W., Jang, W. S., Kim, Y. H., Kim, S. K., Lee, B. E. and Song, H. Y. (2016). Antimycobacterial activity of methanolic plant extract of Artemisia capillaris containing ursolic acid and hydroquinone against Mycobacterium tuberculosis. Journal of Infection and Chemotherapy, 22, 200-208.

Kalchayanand, N., Sikes, A., Dunne, C. P. and Ray, B. (1998). Interaction of Hydrostatic Pressure, Time and Temperature of Pressurization and Pediocin AcH on Inactivation of Foodborne Bacteria. Jornal of Food Protection, 61(4), 425-431.

Kim, J., Marshall, M. R. and Wei, C. (1995). Antibacterial activity of some essential oil components against five foodborne pathogens. Journal of Agricultural and Food Chemistry, 43(11), 2839-2845.

Kivanç, M., Akgül, A. and Doan, A. (1991). Inhibitory and stimulatory effects of cumin, oregano and their essential oils on growth and acid production of Lactobacillus plantarum and Leuconostoc mesenteroides. International Journal of Food Microbiology, 13(1), 81-85.

Lozano Rodríguez, A. G., Arvizu Medrano, S., Padilla Frausto, J. J., Pérez, A. G. and Ibarra Vallejo, J. L. (1992). Evaluacion del desarrollo microbiano y comportamiento a diferentes condiciones de Leuconostoc carnosum. Universidad Autonoma de Queretaro, (1), 1-4.

Mataragas, M., Metaxopoulos, J., Galiotou, M. and Drosinos, E. H. (2003). Influence of pH on growth and bacteriocin production by Leuconostoc mesenteroides L124 and Lactobacillus curvatus L442. Meat Science, 64, 265-271.

Michelena, G., Almeida, G., Altuna, B., Eng, F., Legrá, S., Oliveros, M. and Armenteros, S. (2005). Efecto inhibidor del ácido jasmónico sobre el crecimiento de bacterias y hongos. Instituto Cubano de Investigaciones de los Derivados de la Caña de Azúcar, 39, 3-7.

Militello, M., Settanni, L., Aleo, A., Mammina, C., Moschetti, G., Giammanco, G. M., Blazquez, M. A. and Carrubba, A. (2011). Chemical Composition and Antibacterial Potential of Artemisia arborescens L. Essential Oil. Current Microbiology., 62(4), 1274-1281.

Mulet, R. A. C., Ledesma, J. Á., Vanegas, J. A. D. and Argote Vega, F. E. (2010). Aislamiento y control microbiológico en Leuconostoc mesenteroides, en un ingenio para optimizar el rendimiento de azúcar y etanol. Biotecnología en el Sector Agropecuario y Agroindustrial, 8(2), 31-40.
National Center for Biotechnology Information, U.S. National Library of Medicine. (2016, January 1). Retrieved from https://blast.ncbi.nlm.nih.gov/Blast.cgi

Pujato, S. A., Guglielmotti, D. M., Ackermann, H. W., Patrignani, F., Lanciotti, R., Reinheimer, J. A. and Quiberoni, A. (2014). Leuconostoc bacteriophages from blue cheese manufacture: Long-term survival, resistance to thermal treatments, high pressure homogenization and chemical biocides of industrial application. International Journal of Food Microbiology, 177, 81-88.

Radha Krishnan, K., Babuskin, S., Azhagu Saravana Babu, P., Sasikala, M., Sabina, K., Archana, G., Sivarajan, M. and Sukumar, M. (2014). Antimicrobial and antioxidant effects of spice extracts on the shelf life extension of raw chicken meat. International Journal of Food Microbiology, 171, 32-40.

RStudio. (2015). (3.2.1) [Software]. Retrieved from https:// www.rstudio.com/.

Samelis, J. and Georgiadou, K. G. (2000). The microbial association of Greek taverna sausage stored at 4 and $10^{\circ} \mathrm{C}$ in air, vacuum or $100 \%$ carbon dioxide, and its spoilage potential. Journal of Applied Microbiology., 88(1), 58-68.

Settanni, L., Palazzolo, E., Guarrasi, V., Aleo, A., Mammina, C., Moschetti, G. and Germanà, M. A. (2012). Inhibition of foodborne pathogen bacteria by essential oils extracted from citrus fruits cultivated in Sicily. Food Control, 26(2), 326-330.

Settanni, L., Randazzo, W., Palazzolo, E., Moschetti, M., Aleo, A., Guarrasi, V., Mammina, C., San Biagio, P.L., Marra, F. P., Moschetti, G. and Germanà, M. A. (2014). Seasonal variations of antimicrobial activity and chemical composition of essential oils extracted from three Citrus limon L. Burm. cultivars. Natural Product Research, 28(6), 383-391.

Teixeira, B., Marques, A., Ramos, C., Neng, N. R., Nogueira, J. M. F., Saraiva, J. A. and Nunes, M. L. (2013). Chemical composition and antibacterial and antioxidant properties of commercial essential oils. Industrial Crops and Products, 43, 587-595.

Thoroski, J., Blank, G. and Biliaderis, C. (1989). Eugenol Induced Inhibition of Extracellular Enzyme Production by Bacillus subtilis. Journal of Food Protection, 52(6), 399-403.

Vermeiren, L., Devlieghere, F., Vandekinderen, I., Rajtak, U. and Debevere, J. (2006). The sensory acceptability of cooked meat products treated with a protective culture depends on glucose content and buffering capacity: A case study with Lactobacillus sakei 10A. Meat Science, 74(3), 532-545.

Wilkinson, J. M., Hipwell, M., Ryan, T. and Cavanagh, $\mathrm{H}$. M. A. (2003). Bioactivity of Backhousia citriodora: Antibacterial and Antifungal Activity. Journal of Agricultural and Food Chemistry, 51(1), 76-81. 